\title{
Appraising Independent Mobility of Children in Military Barrack Community Milieu of Developing Countries
}

\author{
Tosin Daodu, Ismail Said \\ Faculty of Built Environment, \\ Universiti Teknologi Malaysia, Skudai, Malaysia \\ daodutosin1@gmail.com, ismailsaid@gmail.com
}

\begin{abstract}
Independent mobility refers to children's liberty to play freely in the neighborhood without been supervised by adults. However, mobility restriction has affected child-friendliness in military barrack community in developing countries including Nigeria. The study aimed to explore principles of independent mobility in creating child-friendly barrack. Thirty journal articles related to children's environment studies, military geographies and barrack housing were reviewed and analyzed. Children's level of independent mobility impacts their physical, social, cognitive, and emotional developments. Consequently, walking or cycling-friendly environment as active travel mode was found to have positively contributed to improved well-being and quality of life of children in military barracks.

Keywords: Independent Mobility, Child-friendly Environment, Active Travel Mode, Military Barrack Community

eISSN 2514-751X @ 2018. The Authors. Published for AMER ABRA cE-Bs by e-International Publishing House, Ltd., UK. This is an open-access article under the CC BY-NC-ND license (http://creativecommons.org/licenses/by$n c-n d / 4.0 /$ ). Peer-review under responsibility of AMER (Association of Malaysian Environment-Behaviour Researchers), ABRA (Association of Behavioural Researchers on Asians) and cE-Bs (Centre for EnvironmentBehaviour Studies), Faculty of Architecture, Planning \& Surveying, Universiti Teknologi MARA, Malaysia.
\end{abstract}

https://doi.org/10.21834/aje-bs.v3i11.329 


\subsection{Introduction}

Children's opportunity of free play in a neighborhood without adult's supervision is largely determined by active travel mode especially walking and cycling. It supports cognition development, sense of identity, freedom, responsibility, confidence, self-esteem, and social skill. The general public perception occasioned in some studies that children have lost their free range poses threat to their wellbeing and quality of life. However, this has continued to find support in the literatures. Although, it was argued that many Americans have a militarized idea following the contemporary security challenges and everyday experience as if attack and defense principle of warfare is a subjective life construct. Invariably, public space too which fosters socialization has equally diminished and the public sphere continued to be perceived as dangerous and begging for control of those unprepared for act of war. Globally, Armed Forces Barracks, installations, and Police Barracks are built in the low densely populated areas of towns and cities to protect national security interests. Military installations are particularly of sizeable expanse of land strategically located in outskirts to enable training exercises and usually far away from the general public. However, high traffic locations are avoided to allow for future expansion and upgrade to meet projected personnel population. Unfortunately, many of the barracks and installations have since merged with neighborhood and business districts due to urban expansion.

In the real sense, the milieu in this study refers to a surrounding culture, family, neighborhood, school, people and everything that makes up the surroundings of military barracks. It also means the environmental condition and multicultural environment in which someone acts or lives and works. Moreover, it envelops economic disparity, class mobility, cultural values and gender roles. Sometimes the milieu shapes a person. The military barracks range from small outposts to military cities containing up to 100,000 people. Barracks establishment is usually determined by its function and population of personnel to be quartered. The roles of the military in national defense, internal operations, peace keeping and humanitarian intervention necessitated the establishment of many military barracks in the developing countries including Nigeria. Typically, the operation area is often restricted, only authorized persons are permitted access irrespective of whether is a military personnel or not. Military barracks community usually provide a condominium housing estate with shared facilities for military personnel, offices and dining facilities. They also provide support facilities such as fast food restaurants, snack bar, gas station, religious centre (churches and mosque), schools, hospital or clinic, shopping and convenience retail stores, beauty saloon, and laundromats. Sporting facilities such as fitness centres, libraries, athletic fields, basketball hoops, child development centres automotive workshops, hobby/arts and crafts centres, bowling centres, and community activity centres. Based on this, an understanding of the military geography, culture and its built environment in developing countries is necessary as the bedrock for assessing independent mobility towards creating a childfriendly military barrack community. The geographical space of military barracks community can be harnessed by representations like maps, models, and how children can make decisions using such representations without compromising the security. It is important to note that military barracks community is a reflection of the society in terms of culture, social, 
political, economic and other policies that affect human existence. Noteworthy, is the goal of civil-military relations that enable socio-economic facilities in barracks such as hospitals, religious centres, markets, and schools provide services for the public in developing countries including Nigeria.

Nevertheless, the study on children's mobility was first analyzed in the 1990s by measuring the territorial range which implies the geographical distance from children's home to places where they have freedom to play and socialize (Kyttä et al., 2015). The concept of independent Mobility was later operationalized as a license to move around freely without adult's accompaniment in the environment. Meanwhile, the degree of a mobility license started with rules laid by parents concerning children's permission to cross roads or to ride a bicycle freely (Kyttä et al., 2015). It was also complemented later by studies on the degree of licenses to visit friends and shopping malls on their own. Other studies have attempted to measure the free range to destinations within a certain period of time. This was achieved by using records of mobility. Due to further advancement in technology, infrastructure for population, longitudinal data connections, geospatial mapping, and statistical software makes it possible to systematically test complex hypotheses. Independent mobility enhances physical activity and children's opportunity to learn through interaction with their surroundings in past studies conducted (Hanapi \& Ahmad, 2016). In addition, the overall effect of independent Mobility indicators and built environment on children's quality of life employed active travel like walking. Despite the benefit of independent mobility to quality of life, children's health and wellbeing, this behavior has declined in many developed and developing countries including the military barrack communities across Nigeria(Fyhri et al., 2011). Likewise, children's degrees of license to travel freely have reduced in many countries including Britain Australia, the USA, Sweden, and in Finland as found in recent studies (Glenn, 2017). The average time per week children spend in active travels like walking and cycling has reduced over the years (Tranter \& Sharpe, 2012) as children's home school journey by car has increased. Further review of articles through national surveys showed reduction in active travel which suggests a simultaneous decrease in opportunities for independent travel. Other studies also have revealed that children's ability to travel independently in communities to public spaces in leisure time has reduced. This is attributable to factors such as security and safety, stranger's danger, urbanization, traffic, and parental fears. Parent's safety-consciousness was found to override the benefits of independent mobility in many countries. Some other studies have showed significant relationship between parental safety perception and children's active travel. This include studies on independent mobility with differences due to inconsistencies in defining and measuring the parameters such as importance of public open space (Chaudhury et al., 2015). In which case, children are limited between home, school and places for children's destinations under adult's supervision. The negative effect is attributable to rampant cases of kidnapping, armed robbery, rituals, and human trafficking. Likewise, the crime reports from media of children being abducted by strangers in public spaces are perceived to be responsible for parents' fear of safety, especially in Nigeria with far reaching impact on barracks community and children's quality of life. 
On the other hand, the independent and active mobility to school, friends and leisure activities involved changes in socio-cultural and neighborhood attributes as well as policy issues (Fyhri et al. 2009). Individual and family features that were found to have affected independent mobility include age, maturity and gender, family structure, socioeconomic status, ethnicity, gender of parent, and parent employment. It also includes minor factors such as weight of school bags, convenience, family spending time together, and trip chaining. Environmental factors like weather, urban form, pathways, connectivity of green spaces, and distance to school and other destinations also affect independent mobility. Similarly, the role of social trust and conception of risk have been identified as important factor on decision making about children's freedom to move around independently (Zhang, Yao, \& Liu, 2017). Other related challenges with low independent Mobility include cognitive, emotional, and social developmental impacts which increases family time for chauffeuring. Since the factors affecting loss of mobility and impacts vary geographically, research need to consider different settlement areas as major parameter.

Studies on school travel as an indicator in Finland, Norway, and Japan have been identified to have a higher level of independent mobility compared with other countries. It was found that $26 \%$ of English and $33 \%$ of Australian children moved freely to and from school. In contrast, levels of independent mobility are more reflective of income as important parameter, with children from poorer backgrounds experiencing much higher levels of independent mobility than those from their richer counterparts in developing countries. It means that wealthier children experienced less independent mobility. Finally, most studies focused on inner urban and suburban neighborhoods that do not reflect the diversity of settlement patterns in which children live of which the barrack community in developing countries is essential. Existing researches in developing countries have limited capacity to inform effective policies and interventions to further a research agenda that will fill existing gap in the literature. To avoid the pitfall of past studies on military barrack space a review of parameters and findings in literatures on related areas is necessary. On this notes, this study begins with an overview of the military geographies, culture and its built environment. It also appraised active travel modes with focus on home-school journey and other destinations. Lastly, factors inhibiting independent mobility with various parameters and its implication on children was reviewed based on lessons from developed countries to create child-friendly military barrack communities in Nigeria.

\subsection{Literature Review}

In order to appraise independent mobility of children in military barrack milieu of Nigeria, the literature review will cover a brief overview of military geographies, culture and its built environment, active travel modes and some factors of independent mobility that affects children's quality of life.

\subsection{An Overview of Military Geographies, Culture and its Built Environment}

The research on independent mobility towards child-friendly cities in most developing 
countries is confronted with challenges of lack of national data, policies, acts, improper planning regulation and implementation. Also inhibiting the study is dearth of information and in-depth researches on children and environment as obtainable in developed countries. Hence, these studies seek to review articles available from developed countries and unpublished articles from developing countries. The domain of barrack is chosen as a case study in developing countries for a pilot study being a sizable community that has all facilities required for the study as earlier mentioned. This will eventually lead to research that will encompass a city in the future. The fact that military barrack conduct security checks or set up a time restriction to control influx like any other condominium housing estate does not make it completely restricted. On the other hand, military geographies can be expressed from the perspective of how military activities and institutions are constituted geographically. It covers a wide scope including analysis of military land use and the environmental impacts of military activities, explorations of representations and interpretation of military landscapes. It also involves investigations into the economic and social relations of military capabilities and the lifestyle of military personnel. The military environmental discourses draw its inspiration from related literatures which involves the cultural geography that argues a general term of space and place viewed not as a given entities existing outside of social practice (Agatha Herman, Richard Yarwow, 2014). Most analysts are concerned with the way natural environment are constituted through a number of social and cultural practices.

The historical and comparative exploration of military culture covers the relationship between military culture and the larger society. The study of military culture is not exhaustive and not limited to the conduct of war but the study of those beliefs, norms, values, rituals, and other symbolic productions that organize and sustain military organizations. The uniqueness of the military reflects in preparation and conduct of ceremonies, military discipline, etiquette, staff work, and military technology that affects residents especially the children. The regimental, bullying, and hazing culture have affected environmental friendliness of barracks and perception of children independent mobility by parents in travel mode choices. Therefore, little or nothing has been said on children and opportunity to harness independent mobility in advancing child-friendly military barracks community in developing countries including Nigeria.

Until the early eighteenth century, soldiers' lives with private citizens or in rented motels which later became insufficient for troop living and sleeping needs. In addition, discipline, absence without official leave, and desertion were difficult to control. Thus, the First British barracks were built in Ireland in 1713 and England in 1721 designed by Mr. Nicholas Hawksmoor. Barracks varied in size and design but they were typically organized around a barrack square. Usually overcrowded, troops were allocated only 200-300 cubic feet of air per man. In comparison, prisoners were allocated a minimum of 600 cubic feet of air per man. The conventional concept of the military's place in society as evolved from the Western experience emphasizes organizational separation of the military. Contemporary security issues like ethno religious, economic, political crisis, internal security problems such as militancy; insurgency, kidnapping and other transnational crimes have necessitated the maintenance of large military population and barracks in developing countries especially in 
Nigeria. The population of children in barracks is more than adults especially ages of 6-12 years in primary schools. This explains why 2 or more primary schools are established in large barracks like Air Force Base Lagos, Kaduna, and Makurdi in Nigeria.

Meanwhile, barrack is a term used for a built environment set up for military and paramilitary housing purposes. Notably, the operation, training and equipment storage area is restricted while the other zones are semi-public and public where children relate with their environment. Although this study is limited to military barrack but the result and finding in the research is applicable to para-military barracks and other housing estates in the developing countries. The right of children to officially reside with parents is adequately provided for in the Harmonized Terms and Condition of Service with maximum age of 18years (HTACOS, 2018). Government and military authorities in Nigeria have made efforts to ensure children participation in barracks activities with the provision of schools, and play areas but still have a lot to do in making barracks child-friendly. Barracks therefore remain Government and public interest in developing countries as posited by Okafor, BN (2016). He used the military and police barracks as a case study of public institution.

\subsection{Active Travel Modes Experience of Children in Barrack Milieu}

Studies on children's independent mobility and active travel modes considered walking, cycling, car, and public transport as variables. Studies showed that children's freedom to explore their cities independently or by active travel modes have reduced in many western nations since 1970s, However, literature on design, urban form, and transport indicates steps to change societies and promote children's freedom in active travel and mode choice to school (Zhang et al., 2017). It was discovered that more is required than the implementation of travel behaviour change programs of which the main issue is lack of effective strategies to inspire children and parents. Moreover, urban areas including barracks in developing countries have witnessed massive use of the private car as a daily means of travel. This is largely responsible for congestion, waste of time looking for a parking place, and stressful situations that affects quality of life. Other impacts are inefficient use of resources, atmospheric and noise pollutions. Meanwhile, the dimension of non- motorize practices such as preferences of street characteristics for walking offers a critical perspective on mobility policies and construction of local travel space (Ernawati, 2016). Insights from a case study of Copenhagen on declines in children's active transport and independent Mobility have been spontaneous in many western nations over recent decades. Despite the growing understanding of policy changes that would lead to increase in children's active travel, it has not been possible to reverse the trends in children's mobility in most nations.

Another study explored the prevalence of walking in home school journey for ages between 11 to 13 years. Physical activity such as walking to school has emerged in response to the increased prevalence of sedentary lifestyle in children. Public health practitioners and urban planners carried out a survey and monitor walking practices in space and time. This was done with a view to developing appropriate interventions. Evidence suggests that interventions to increase active school transportation need to acknowledge spatial and temporal differences in walking behaviour. Moreover, other researchers have examined 
differences in school transport between urban and rural places. It was found that urban children tend to walk more for school purposes than others. The provision of sidewalks was significantly related to active school travel, while other design characteristics such as intersection density tend to negatively correlate with the walking.

Children's freedom to move independently in their environment is a key feature of a childfriendly environment especially in poor neighborhood (Ghanbari-azarneir, Anbari, \& Hosseini, 2015). Parent's dilemma regarding the perception of being seen as faring poorly result in social traps which is responsible for failure of policies to walk. Social trap occurs when parents make decisions about their child's travel behaviour without the knowledge of what other parents might be doing. Parents then feel trapped into chauffeuring their child to and from school and into preventing them from cycling or walking as a means of home school journey. It may be due to traffic volume around school that make parent feel that it is dangerous to allow their children walk or cycle to school and other play areas as children do have preferences for outdoor environment especially in school. Parents also have the fears that others will perceive them as uncaring parents by not conforming to chauffeuring culture. The remedy to social traps is to allow intervention between individual parents and caregivers which can advance into forum for collective decision making about children active travel and mode choice behaviour. Parent's awareness of the negative consequences of car dominated travel on their children's health due to lack of physical activity will help in travel mode choice behaviour,in barracks and this can change with such intervention. Similarly, studies revealed in Asian cities that people work less than before and children are less active than before (Cubukcu et al., 2015). Based on this, impacts of mobility restriction on children was examined drawing lessons from previous studies in developed and developing countries to appraise military barrack.

\subsection{Factors of Independent Mobility that Affect Children's Quality of Life}

Mobility restriction is basically an outcome of rural urban migration, high volumes of traffic, parents' perception of social dangers, and the recalcitrance attitudes of children. Other parameters such as convenience, weather conditions or school compulsory restrictions are parents' considerations to drive their children to school instead of walking. Studies conducted on mobility restrictions showed that children's home school journey in Italy have been affected. It was also found that $71 \%$ of children between the ages of 7 to 12 years were escorted by adults to and from school. Similarly, it was discovered that mobility restriction affects female children than male. Moreover, size and the densities of a city are fused to the opportunities for independent mobility. Notably, results of past researches indicated that children in the rural or lower-density neighbourhood enjoyed higher degree of licence compared to children in high-density city environment (Villanueva et al., 2012). Although the actual mobility has not corroborated the extent of possibilities the rural children have to travel around independently in contrast with urban children. Consequently, the neighbourhood also have an impact on children's independent mobility (Kolodinsky et al., 2013). Studies from many developed countries have shown reduction in the prevalence of active travel and independent mobility (Timperio, \& Crawford, 2008). Since 2002 only about $40 \%$ of UK 
children 7-13 years have been allowed freedom of home school journey without supervision (Fyhri \& Hjorthol, 2009) and a recent research conducted in Australia revealed that less than $46 \%$ of children walk or cycle to school and below $38 \%$ are free to travel. Emerging evidence suggests that active transport to and from school increases with age during childhood, particularly from childhood to adolescence, though some studies have shown that active transport declines with age (Tranter et al., 2012). Individual, social and physical environmental level factors influence independent mobility and physical activities behaviour (Veitch et al., 2017).

On the other hand, the traffic and safety measures put in place by creating trafficseparated areas influences children's mobility with emphasis on the importance of neighborhood cohesion and connectedness (Lin et al., 2017). It was further revealed that children living in apartment buildings with courtyards close to the parks in Rome and in new neighbourhoods enjoyed independent mobility. Friends can also influence a child to travel around freely. Likewise, studies conducted in different countries indicated that the degree of liberty enjoyed by Finnish children to travel around without accompaniment is higher than children in many other countries. The other children with relatively low degrees of license were found in Australia, Italy, and Portugal.

In the European context, the perception of social dangers in the middle European countries is greater than Scandinavian countries. Children seem to be apprehensive of people than traffic. As such, children's level of independent mobility affects their physical, social, cognitive and emotional development. In another study conducted, a decline in the motor and social development of 5-year olds was observed. Children were noticed to be deficient in playing independently outdoors, streets, and in open yards. Furthermore, studies have equally emphasized the importance of spontaneous outdoor play on children's motor physical development. Mobility restrictions also have significant impact on the development of emotional bonds between children and the natural environment. Thereby, a sense of responsibility for the environment is developed. Moreover, the research that investigated the mobility restriction of children residing in a low-income area of core London shows that $90 \%$ of the children have difficulty making reference to meaningful place. Meanwhile, in their research on rural children in the UK, Matthews et al. $(2000 a, b)$ found that social places were more significant to children than natural places. This was due to children's restriction to natural environment owing to parental fears and fencing-off of private land. Nevertheless, a study finds no relationship between mobility licenses and meaningful place or its distance from home. Consequently, some studies analysed the impacts of mobility restriction on the development of independence and identity formation. This was buttressed by a study that revealed 5-year olds who played independently in their neighbourhood making references to diverse and rich set of activities and play compared with children of the same age that played regularly in playgrounds.

Furthermore, a number of studies have indicated that actual mobility promotes a sense of knowledge acquisition, planning and structuring of child-friendly environment in poor neighborhood (Ghanbari-azarneir et al., 2015). Apart from the influence of mobility restrictions on children's development, broader effects on society are noticeable in these 
studies. The reduction in children's independent mobility causes additional time that parents requires for chauffeuring and shrinks their free time. It was found in other studies that several countries with traffic jams on home school journey have challenge. In general, reduction in children's independent mobility is a major constraint towards promoting active travel-mode choices and the concept of child-friendly environment. Nevertheless, dearth of information on the relevance of independent mobility as against the wrong perception of people in relation to the mobility restriction in military barracks community have created a gap for further study in children's environment and human behaviors. This has equally led to the deprivation of thousands of children living in barracks of adequate wellbeing and quality of life in developing countries including Nigeria.

\subsection{Methodology}

In an attempt to appraise independent Mobility of children in the Military barracks community, this study made use of search process in order to select relevant studies for review. Journal articles obtained through electronic databases from UTM e-library, Google scholar, Science Direct and AMER Publications from 2012 to 2017 were used. Comments were made based on personal observations on parameters and findings in bringing out the gap for further studies during the metal-analysis. The search range was from 1989-2018 publications. Though, it was stated earlier that the study of children and nature dates back to 18th century as introduced by romantic literature, but all necessary documents were searched up to 1979 in related areas. Selective search was performed from journals of social sciences and humanity, environmental psychology, health and place. Multi-disciplinary journals in built environment, urban planning, transport geography and geography of military were also reffered. It was revealed that the journals of transport and health published the largest percentage of articles on the subject. Search terms included independent mobility, mobility restriction, active travel, child-friendly environment, land use, and active travel Furthermore, personal observation reference lists of the selected publications were checked to identify more studies as well as personal profiles of notable authors for further information.

Additionally, the interfaces between the independent mobility and built environment that can help develop child friendly military barrack community in related discipline were considered and viewed in the context of the military barracks milieu for further studies. Relevant studies were consulted including unpublished theses and articles as related works on military barracks specific to children and environment are inadequate. A total of 30 journal articles relevant to the topic were selected and reviewed (see Table 1). The reviewed study considered how most of the parameters influences the outcome and how findings can assist in advancing child-friendly military barrack community context towards improved quality of life in developing countries especially Nigeria. 
Table 1: Articles Reviewed

\begin{tabular}{|c|c|c|c|c|}
\hline NO & $\begin{array}{l}\text { TITLE, } \\
\text { AUTHOR/YEAR }\end{array}$ & PARAMETERS & FINDINGS & $\begin{array}{l}\text { LIMITATION/ } \\
\text { FUTURE } \\
\text { AREA }\end{array}$ \\
\hline 1 & $\begin{array}{l}\text { Children's } \\
\text { neighborhood place as } \\
\text { a psychological and } \\
\text { behavioral domain } \\
\text { Byungho Min, } \\
\text { Jongmin Lee (2006) }\end{array}$ & $\begin{array}{l}91 \text { children living in } \\
\text { a large high rise, } \\
\text { high density } \\
\text { planned } \\
\text { neighborhood of } \\
5277 \text { families are } \\
\text { involved. }\end{array}$ & $\begin{array}{l}{ }^{*} \text { The place map showed } \\
\text { children's important places } \\
\text { as spatially skewed and the } \\
\text { layout and location not a } \\
\text { large factor } \\
\text { *affordances related to } \\
\text { location and spatial qualities } \\
\text { of setting offered sense of } \\
\text { territoriality }\end{array}$ & $\begin{array}{l}\text { Reliance on other } \\
\text { observational } \\
\text { protocols to expand } \\
\text { knowledge of multi- } \\
\text { functionality of place } \\
\text { to the child's } \\
\text { neighborhood } \\
\text { experiences. }\end{array}$ \\
\hline 2 & 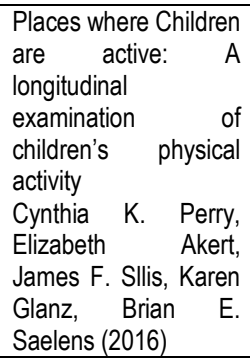 & $\begin{array}{l}\text { Two-year } \\
\text { longitudinal data at } \\
\text { two points (2007- } \\
2009 \text { ) and 2009- } \\
2011) \text { with children } \\
\text { living in the } \\
\text { metropolitan areas } \\
\text { of San Diego, } \\
\text { parents recorded } \\
\text { their children's } \\
\text { location for 7-days }\end{array}$ & $\begin{array}{l}\text { An examination of R-squared } \\
\text { values across models shows } \\
\text { that covariates such as age, } \\
\text { gender, and site explains } \\
\text { higher proportion of variance } \\
\text { in activity levels at T2 than } \\
\text { neighborhood activity } \\
\text { measures alone }\end{array}$ & $\begin{array}{l}\text { Children spend little } \\
\text { time outside homes } \\
\text { in their } \\
\text { neighborhood. } \\
\text { Reduction of time } \\
\text { inside home and } \\
\text { increase time outside } \\
\text { in the neighborhood } \\
\text { becomes necessary } \\
\text { for older children }\end{array}$ \\
\hline 3 & $\begin{array}{l}\text { The impact of } \\
\text { playground spatial } \\
\text { features on children's } \\
\text { play and activity forms: } \\
\text { An evaluation of } \\
\text { contemporary } \\
\text { playgrounds' play and } \\
\text { social value } \\
\text { Magdalena } \\
\text { Czaczynska-Podolska } \\
\text { (2014) }\end{array}$ & $\begin{array}{l}\text { No variables in the } \\
\text { quantitative } \\
\text { analysis. Gender } \\
\text { was considered. } \\
\text { Ten selected } \\
\text { contemporary } \\
\text { playgrounds were } \\
\text { analyzed }\end{array}$ & $\begin{array}{l}\text { Play reported for between } \\
43 \%-1.1 \% \text { of } \\
\text { observations. The result for } \\
\text { non-play activity and non- } \\
\text { play/non-activity were } \\
\text { highest in case of } \\
\text { communication and open } \\
\text { areas }\end{array}$ & $\begin{array}{l}\text { The study suggested } \\
\text { that contemporary } \\
\text { playgrounds can } \\
\text { have strong play and } \\
\text { social potential } \\
\text { exploring functional } \\
\text { factors and diverse } \\
\text { influences }\end{array}$ \\
\hline 4 & $\begin{array}{l}\text { Children's Views on } \\
\text { Child-Friendly } \\
\text { Environments in } \\
\text { Different Geopolitical, } \\
\text { Cultural and Social } \\
\text { Neighborhoods. } \\
\text { Maria } \\
\text { Nordstrom(2007) }\end{array}$ & $\begin{array}{l}\text { 12-year-old } \\
\text { children living in } \\
\text { geographical, } \\
\text { cultural and socially } \\
\text { different urban } \\
\text { neighborhoods. }\end{array}$ & $\begin{array}{l}\text { The result shows that three } \\
\text { dimensions in particular } \\
\text { apply to the children's } \\
\text { responses. Therefore there } \\
\text { is need for change in current } \\
\text { city planning practice. }\end{array}$ & $\begin{array}{l}{ }^{*} \text { Adults views not } \\
\text { compare with } \\
\text { children in the study. }\end{array}$ \\
\hline 5 & $\begin{array}{l}\text { Association between } \\
\text { the built environment } \\
\text { and children's } \\
\text { independent mobility: } \\
\text { A metal-analytic } \\
\text { review } \\
\text { Samia Sharmin, Md. } \\
\text { Kamruzzaman (2018) }\end{array}$ & $\begin{array}{l}7-12 \text { years old } \\
\text { children living in a } \\
\text { poor neighborhood }\end{array}$ & $\begin{array}{l}\text { It was found that places } \\
\text { offering varieties of play } \\
\text { opportunities are more likely } \\
\text { to become children's favorite } \\
\text { among liked places. }\end{array}$ & $\begin{array}{l}\text { After safety, the main } \\
\text { concern should be to } \\
\text { provide a variety of } \\
\text { affordances for play. }\end{array}$ \\
\hline
\end{tabular}


Daodu,T., \& Said, I. / Asian Journal of Environment-Behaviour Studies (ajE-Bs), 3(11) Nov / Dec 2018 (p1-18)

\begin{tabular}{|c|c|c|c|c|}
\hline 6 & $\begin{array}{l}\text { Physical } \\
\text { environmental } \\
\text { characteristics } \\
\text { promoting } \\
\text { independent and } \\
\text { active transport to } \\
\text { children's meaningful } \\
\text { places/Anna Broberg, } \\
\text { Samuli Salminen, } \\
\text { Marketta Kytta(2013) }\end{array}$ & $\begin{array}{l}13 \text { BE-CIM links } \\
\text { and published } \\
\text { between } 1980 \text { and } \\
2016 . \text { Overall effect } \\
\text { size (ES), using the } \\
\text { reported results } \\
\text { from the primary } \\
\text { studies and based } \\
\text { on a random effect } \\
\text { model }\end{array}$ & $\begin{array}{l}\text { Four BE factors with } \\
\text { positive CIM association , } \\
\text { traffic neutral association, } \\
\text { and the remaining eight } \\
\text { factors with negative } \\
\text { association. Living in a dead } \\
\text { end street was found to have } \\
\text { the strongest positive ES } \\
\text { (0.352), with moderate level } \\
\text { of consistency across the } \\
\text { primary studies. }\end{array}$ & $\begin{array}{l}\text { Limitation in term of } \\
\text { aggregation of } \\
\text { different CIM } \\
\text { dimensions to derive } \\
\text { overall ES. } \\
\text { Finding serve as a } \\
\text { guide for policy } \\
\text { makers on urban } \\
\text { design } \\
\text { It finally unveil the } \\
\text { reason for } \\
\text { inconsistent finding } \\
\text { on this topic. }\end{array}$ \\
\hline 7 & $\begin{array}{l}\text { What neighborhood } \\
\text { area captures built } \\
\text { environment features } \\
\text { related to adolescent } \\
\text { physical activity? } \\
\text { Janne Boone- } \\
\text { Heinonen Barry } \\
\text { M.Popkin,YanSong } \\
\text { Penny Gordon-Larsen } \\
\text { (2017) }\end{array}$ & $\begin{array}{l}\text { 7-12 years old } \\
\text { children over } 3 \\
\text { years }\end{array}$ & $\begin{array}{l}\text { Trees are intriguing and } \\
\text { multifaceted, satisfying many } \\
\text { of the children's private and } \\
\text { social needs. }\end{array}$ & $\begin{array}{l}\text { Exploitation of tree } \\
\text { affordances during } \\
\text { place-based play } \\
\text { reflected } \\
\text { connectedness to } \\
\text { place and utilization } \\
\text { of trees became } \\
\text { more versatile over } \\
\text { time }\end{array}$ \\
\hline 8 & $\begin{array}{l}\text { 'Being on the move': } \\
\text { Time-spatial } \\
\text { organisation and } \\
\text { mobility } \\
\text { in a mobile preschool } \\
\text { Katarina Gustafson } \Uparrow, \\
\text { Danielle van der } \\
\text { Burgt(2015) }\end{array}$ & $\begin{array}{l}\text { GIS- derived } \\
\text { characteristics of } \\
\text { interest PA(MVPA) } \\
\text { and PA facility and } \\
\text { street connectivity } \\
\text { within } 1,3,5 \text { and } \\
8.05 \mathrm{~km}\end{array}$ & $\begin{array}{l}\text { BE-MVPA relationship varied } \\
\text { by BE characteristic. higher } \\
\text { MVPA was generally related } \\
\text { to resource counts and } \\
\text { intersection density within } 1- \\
5 \text { and } 1 \mathrm{~km} \text { of respondents } \\
\text { homes }\end{array}$ & $\begin{array}{l}\text { More research in } \\
\text { diverse geographic } \\
\text { areas, as well as } \\
\text { further examination } \\
\text { of age and sex } \\
\text { differences is } \\
\text { required }\end{array}$ \\
\hline 9 & $\begin{array}{l}\text { Children's } \\
\text { independent mobility } \\
\text { in Portugal: effects of } \\
\text { urbanization degree } \\
\text { and motorized modes } \\
\text { of travel } \\
\text { F. Lopes, R. Cordovil, } \\
\text { C. Neto (2018) }\end{array}$ & $\begin{array}{l}22 \text { of } 4-5 y e a r s \text { old } \\
\text { children both boys } \\
\text { and girls, in a } \\
\text { preschool bus for } \\
\text { Monday to Friday } \\
\text { between 9am to } \\
3 \text { pm }\end{array}$ & $\begin{array}{l}\text { The findings show that the } \\
\text { social order of the mobile } \\
\text { preschool is 'being on the } \\
\text { move' and that the travelling } \\
\text { shapes the time-spatial } \\
\text { organisation, with major } \\
\text { implications for daily routines } \\
\text { and activities }\end{array}$ & $\begin{array}{l}\text { This peculiar study } \\
\text { on the mobile } \\
\text { preschool not usually } \\
\text { covered in the field of } \\
\text { geography to } \\
\text { understand travel } \\
\text { among location and } \\
\text { on children } \\
\text { development through } \\
\text { outdoor learning at } \\
\text { early life }\end{array}$ \\
\hline 10 & $\begin{array}{l}\text { Children's } \\
\text { independent mobility } \\
\text { to school, friends and } \\
\text { leisure activities } \\
\text { Aslak Fyhri/ Randi } \\
\text { Hjorthol(2018) }\end{array}$ & $\begin{array}{l}\text { Mobility license, } \\
\text { actual mobility, fear } \\
\text { of traffic, stranger } \\
\text { danger and sense } \\
\text { of community were } \\
\text { compared in highly, } \\
\text { moderated and } \\
\text { non-urbanized } \\
\text { environments }\end{array}$ & $\begin{array}{l}\text { Increase urbanization leads } \\
\text { to decrease of children } \\
\text { licenses to independently } \\
\text { cross and cycle main roads; } \\
\text { go out after dark and go to } \\
\text { places other than school. } \\
\text { Decrease independent } \\
\text { active home-home travel and } \\
\text { leisure time activities. }\end{array}$ & $\begin{array}{l}\text { Children's freedom } \\
\text { of movement in the } \\
\text { highly urbanized } \\
\text { setting is very } \\
\text { restricted due to a } \\
\text { pervasive } \\
\text { automobile } \\
\text { dependence, } \\
\text { proposing a shift }\end{array}$ \\
\hline
\end{tabular}


Daodu,T., \& Said, I. / Asian Journal of Environment-Behaviour Studies (ajE-Bs), 3(11) Nov / Dec 2018 (p1-18)

\begin{tabular}{|c|c|c|c|c|}
\hline & & $\begin{array}{l}\text { according } \\
\text { gender. }\end{array}$ & $\begin{array}{l}\text { Parental fear regarding traffic } \\
\text { is the most frequent concern } \\
\text { regarding children safety }\end{array}$ & $\begin{array}{l}\text { from a motorized to a } \\
\text { workable city }\end{array}$ \\
\hline 11 & $\begin{array}{l}\text { Citizen involvement in } \\
\text { promoting sustainable } \\
\text { mobility. } \\
\text { Angel Ibeas, Luigi } \\
\text { dell'Olio, Rosa } \\
\text { Barreda Montequin }\end{array}$ & $\begin{array}{l}\text { Parents with } \\
\text { children within 6- } \\
\text { 12years recruited } \\
\text { from NTS 2005. 3- } \\
\text { variables, transport } \\
\text { to school, sports } \\
\text { and friends }\end{array}$ & $\begin{array}{l}\text { Distance to school and } \\
\text { children's age were the most } \\
\text { influential variables on CIM } \\
\text { measured as an index }\end{array}$ & $\begin{array}{l}\text { Future research } \\
\text { should aim at } \\
\text { replicating these } \\
\text { results using data } \\
\text { that are more directly } \\
\text { applicable for SEM } \\
\text { analysis. }\end{array}$ \\
\hline 12 & $\begin{array}{l}\text { Controlling mobility, } \\
\text { performing } \\
\text { boarderwork: cycle } \\
\text { mobility in } \\
\text { Copenhagen and the } \\
\text { multiplication of } \\
\text { boundaries } \\
\text { Anne Jensen(2018) }\end{array}$ & $\begin{array}{l}\text { Group of students } \\
\text { from the university } \\
\text { of Cantabria. Mega } \\
\text { focus group were } \\
\text { held in 3-different } \\
\text { days }\end{array}$ & $\begin{array}{l}\text { The study shows the } \\
\text { necessity of citizen } \\
\text { participation in developing } \\
\text { policies and plans related to } \\
\text { sustainable mobility }\end{array}$ & $\begin{array}{l}\text { The MFG have been } \\
\text { useful in providing a } \\
\text { territorial } \\
\text { representation of } \\
\text { peoples' perception } \\
\text { and opinions through } \\
\text { zoning process }\end{array}$ \\
\hline 13 & $\begin{array}{l}\text { Disney-Pixar to the } \\
\text { rescue: harnessing } \\
\text { positive affect for } \\
\text { enhancing Children's } \\
\text { active mobility } \\
\text { Paul Tranter, Scott } \\
\text { Sharpe }\end{array}$ & $\begin{array}{l}\text { Car } \\
\text { Public transport } \\
\text { Biking } \\
\text { Walking }\end{array}$ & $\begin{array}{l}\text { The study shows that the } \\
\text { policies of socially inclusive } \\
\text { cycle track systems add to } \\
\text { urban boarderwork. }\end{array}$ & $\begin{array}{l}\text { Articulations of a } \\
\text { cycle-dependent to } \\
\text { different categories } \\
\text { of cycling } \\
\text { Copenhageners } \\
\text { embedded in policies } \\
\text { y }\end{array}$ \\
\hline 14 & $\begin{array}{l}\text { Estimating the effect of } \\
\text { mobility and food } \\
\text { choice on obesity in } \\
\text { rural, northern } \\
\text { environment } \\
\text { Jane M. Kolodinsky, } \\
\text { Geoffrey Battista, Erin } \\
\text { Roche H.Y. Lee, } \\
\text { Rachel } \\
\text { Johnson(2017) }\end{array}$ & $\begin{array}{l}\text { Food choice } \\
\text { Obesity } \\
\text { Geographic } \\
\text { location }\end{array}$ & $\begin{array}{l}\text { A broad affective response- } \\
\text { amongst viewers makes } \\
\text { them more open to new } \\
\text { ideas change the way we } \\
\text { think and feel it provides the } \\
\text { clue to a new approach to } \\
\text { energy collector thinking } \\
\text { cognition. }\end{array}$ & $\begin{array}{l}\text { Focus group studies } \\
\text { may provide further } \\
\text { insight into ways in } \\
\text { which such films } \\
\text { could promote } \\
\text { positive effect and } \\
\text { openness to new } \\
\text { ways }\end{array}$ \\
\hline 15 & $\begin{array}{l}\text { The last free-range } \\
\text { children? Children's } \\
\text { independent mobility } \\
\text { in Finland in the 1990s } \\
\text { and 2010s/ Marketta } \\
\text { Kytta, Jukka Hirvonen, } \\
\text { Julie Rudner, Liris } \\
\text { Pirjola, } \quad \text { Tiina } \\
\text { Laatikainen (2017) }\end{array}$ & $\begin{array}{l}\text { Complex } \\
\text { association of } \\
\text { variables with } \\
\text { being overweight or } \\
\text { obsessed were } \\
\text { considered }\end{array}$ & $\begin{array}{l}\text { The result indicate that food } \\
\text { choice, mobility, } \\
\text { demographic characteristics } \\
\text { and normative beliefs are } \\
\text { related to energy imbalance }\end{array}$ & $\begin{array}{l}\text { Further research is } \\
\text { needed to build data } \\
\text { sets that include both } \\
\text { food and activity } \\
\text { environments that } \\
\text { are generalizable } \\
\text { beyond the study } \\
\text { area included in the } \\
\text { study }\end{array}$ \\
\hline 16 & $\begin{array}{l}\text { Gender equality and } \\
\text { women's participation } \\
\text { in transport cycling } \\
\text { Gabriele Prati(2017) }\end{array}$ & Gender parameter & $\begin{array}{l}\text { Four RMEs were identified } \\
\text { and mapped. } \\
\text {-short distance environment, } \\
\text {-motorized environments, } \\
\text {-non-motorized } \\
\text { environments } \\
\text {-long distance environments }\end{array}$ & $\begin{array}{l}\text { Need to unravel the } \\
\text { relationships } \\
\text { between retail } \\
\text { activity and non- } \\
\text { motorized } \\
\text { accessibility, in order } \\
\text { to reach sustainable } \\
\text { planning goals }\end{array}$ \\
\hline
\end{tabular}


Daodu,T., \& Said, I. / Asian Journal of Environment-Behaviour Studies (ajE-Bs), 3(11) Nov / Dec 2018 (p1-18)

\begin{tabular}{|c|c|c|c|c|}
\hline 17 & $\begin{array}{l}\text { Is there a gender gap } \\
\text { in school travel? An } \\
\text { examination of US and } \\
\text { adolescents } \\
\text { Noreen } \\
\text { McDonaid(2012) }\end{array}$ & $\begin{array}{l}\text { Gender of Male } \\
\text { and } \\
\text { Female }\end{array}$ & $\begin{array}{l}\text { The composite indicator of } \\
\text { gender equality index was } \\
\text { associated with women's } \\
\text { participation in transport } \\
\text { cycling }\end{array}$ & $\begin{array}{l}\text { future studies needs } \\
\text { to investigate gender } \\
\text { equality effects in } \\
\text { investment in cycling } \\
\text { infrastructure }\end{array}$ \\
\hline 18 & $\begin{array}{l}\text { The influence of } \\
\text { neighborhood } \\
\text { environment and } \\
\text { household travel } \\
\text { interaction on school } \\
\text { travel behavior: an } \\
\text { exploration using } \\
\text { geographical- } \\
\text { weighted models } \\
\text { Raktim Miltra, Ron N } \\
\text { Buliung (2014) }\end{array}$ & $\begin{array}{l}\text { Male } \\
\text { Female }\end{array}$ & $\begin{array}{l}\text { Males walk to and fro school } \\
\text { more than females }\end{array}$ & $\begin{array}{l}\text { Participation of } \\
\text { females in biking to } \\
\text { school programme }\end{array}$ \\
\hline 19 & 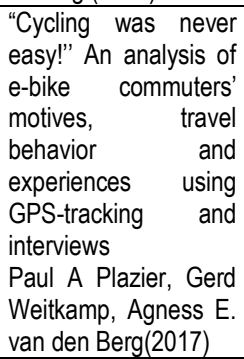 & $\begin{array}{l}\text { Built environment } \\
\text { characteristics } \\
\text { parameter }\end{array}$ & $\begin{array}{l}\text { Result shows that built } \\
\text { environment near both } \\
\text { home and school locations } \\
\text { was associated with the odds } \\
\text { of walking }\end{array}$ & $\begin{array}{l}\text { More research } \\
\text { required to } \\
\text { understand inter- } \\
\text { household } \\
\text { similarities in } \\
\text { behaviors that are } \\
\text { spatially structured. }\end{array}$ \\
\hline 20 & $\begin{array}{l}\text { An explanation of the } \\
\text { relationship between } \\
\text { adults' work trip mode } \\
\text { and children's school } \\
\text { trip mode through the } \\
\text { Heckman approach } \\
\text { Devajyoti Deka(2013) }\end{array}$ & Adults and Children & 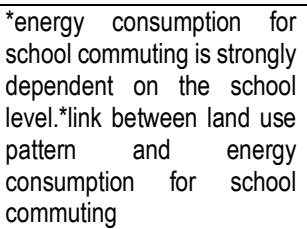 & $\begin{array}{l}\text { Guide future policies } \\
\text { focused on transport } \\
\text { energy consumption } \\
\text { at the local scale }\end{array}$ \\
\hline 21 & $\begin{array}{l}\text { A troublesome } \\
\text { transport challenge? } \\
\text { Working round the } \\
\text { school run } \\
\text { Juliet Jain, Tilly Line, } \\
\text { Glenn Lyons(2011) }\end{array}$ & $\begin{array}{l}\text { Selection } \\
\text { variables }\end{array}$ & $\begin{array}{l}\text { Household adults' decision } \\
\text { to drive to work significantly } \\
\text { increased children being } \\
\text { dropped off at school and } \\
\text { decreases their likelihood of } \\
\text { walking and biking }\end{array}$ & $\begin{array}{l}\text { It suggest that } \\
\text { children's mode } \\
\text { choice studies } \\
\text { should not ignore } \\
\text { how parents or } \\
\text { caregivers travel to } \\
\text { work }\end{array}$ \\
\hline 22 & $\begin{array}{l}\text { The determinant of } \\
\text { commuting mode } \\
\text { choice among school } \\
\text { children in Beijing } \\
\text { Li Shenggxiao.Zhao } \\
\text { Pengnjun (2015) }\end{array}$ & $\begin{array}{l}\text { Time is the major } \\
\text { variable }\end{array}$ & $\begin{array}{l}\text { Time was the problem - } \\
\text { including time for travelling } \\
\text { and coordinating activities in } \\
\text { time and space and being } \\
\text { punctual }\end{array}$ & $\begin{array}{l}\text { The research did not } \\
\text { generate } \\
\text { transferable solution } \\
\text { to transport practice,. }\end{array}$ \\
\hline 23 & $\begin{array}{l}\text { Travel -to school } \\
\text { distances in Sweeden } \\
\text { 2000-2006: changing }\end{array}$ & Cultural context & $\begin{array}{l}\text { It was found that the specific } \\
\text { institutional and cultural } \\
\text { context in Beijing is an } \\
\text { important determinant of }\end{array}$ & $\begin{array}{l}\text { Need to fill the gaps } \\
\text { in travel behavior in } \\
\text { relation to more } \\
\text { school choice, }\end{array}$ \\
\hline
\end{tabular}


Daodu,T., \& Said, I. / Asian Journal of Environment-Behaviour Studies (ajE-Bs), 3(11) Nov / Dec 2018 (p1-18)

\begin{tabular}{|c|c|c|c|c|}
\hline & $\begin{array}{l}\text { school geography with } \\
\text { equality implication } \\
\text { Eva Andersson, Bo } \\
\text { Malmberg, John } \\
\text { Osth(2012) }\end{array}$ & & $\begin{array}{l}\text { school accessibility and } \\
\text { modal spit for junior } \\
\text { secondary school students }\end{array}$ & $\begin{array}{l}\text { school quality and } \\
\text { special distribution of } \\
\text { educational } \\
\text { opportunities }\end{array}$ \\
\hline 24 & $\begin{array}{l}\text { Children aged 9-14 } \\
\text { living in disadvantaged } \\
\text { areas in England: } \\
\text { Opportunities and } \\
\text { barriers for cycling } \\
\text { Nicola Christie, } \\
\text { Richard Kimberlee, } \\
\text { Elizabeth Towner, } \\
\text { Sarah Rodgers, } \\
\text { Heather Ward(2011) }\end{array}$ & $\begin{array}{ll}\text { Distance } & \text { and } \\
\text { Destination } & \end{array}$ & $\begin{array}{l}\text { Travel to school distances } \\
\text { have increased since the } \\
\text { year } 2000 \text {. The pattern of } \\
\text { differential mobility showed } \\
\text { geographical school choice } \\
\text { affect of depleting local } \\
\text { schools in disadvantaged } \\
\text { areas of students with less } \\
\text { disadvantaged background }\end{array}$ & \\
\hline 25 & $\begin{array}{l}\text { A Model Development } \\
\text { for Children's Walking } \\
\text { in Neighborhood } \\
\text { Mansoureh } \\
\text { Rezasoltania*, } \\
\text { Mostafa Behzadfara, } \\
\text { Ismail Saidb(2015) }\end{array}$ & $\begin{array}{l}9-11 \text { year old } \\
\text { children } \\
\text { who are in mid } \\
\text { childhood. }\end{array}$ & $\begin{array}{l}\text { the research, the created } \\
\text { model discovered the } \\
\text { connections between nine } \\
\text { captured factors all together } \\
\text { with } \\
\text { spatial knowledge. In }\end{array}$ & $\begin{array}{l}\text { Studies on more } \\
\text { extensive variables }\end{array}$ \\
\hline 26 & $\begin{array}{l}\text { A Review on } \\
\text { Environmental } \\
\text { Characteristic that } \\
\text { Influence Children } \\
\text { Physical Activities in } \\
\text { Low Cost Housing } \\
\text { Nurul Liyana Hanapi*, } \\
\text { Sabarinah } \\
\text { Ahmad(2015) Sh }\end{array}$ & $\begin{array}{l}\text { Children living in } \\
\text { high-density low- } \\
\text { cost housings, time } \\
\text { spent outdoors }\end{array}$ & $\begin{array}{l}\text { Revealed } 4 \text { physical } \\
\text { characteristics (poor safety, } \\
\text { crowding, inadequate } \\
\text { facilities and poor } \\
\text { neighbourhood } \\
\text { relationship,were found to } \\
\text { be the major contributors in } \\
\text { less physical activities } \\
\text { among children. }\end{array}$ & $\begin{array}{l}\text { More research } \\
\text { regarding the } \\
\text { manipulation of the } \\
\text { physical } \\
\text { environment in low- } \\
\text { cost housing as an } \\
\text { effort to enhance } \\
\text { physical activity } \\
\text { among children is } \\
\text { needed. }\end{array}$ \\
\hline 27 & $\begin{array}{l}\text { Children's Sense of } \\
\text { Attachment to the } \\
\text { Residential Common } \\
\text { Open Space } \\
\text { Maryam Shabak*, } \\
\text { Nima Norouzi, } \\
\text { Aminatuzuhariah } \\
\text { Megat Abdullah, } \\
\text { Tareef } \\
\text { Khan(2015) Hayat }\end{array}$ & $\begin{array}{l}\text { physical } \\
\text { characteristics of } \\
\text { the place, }\end{array}$ & $\begin{array}{l}\text { Designing an open space for } \\
\text { children to fulfill their } \\
\text { physical and mental needs } \\
\text { should be different with } \\
\text { existing adult design } \\
\text { criteria }\end{array}$ & $\begin{array}{l}\text { The relationships } \\
\text { between a sense of } \\
\text { place attachment } \\
\text { and each specific } \\
\text { characteristics of the } \\
\text { place can be more } \\
\text { studied in the future } \\
\text { research. }\end{array}$ \\
\hline 28 & $\begin{array}{l}\text { Dimensions } \\
\text { Underlying Local } \\
\text { People's Preference } \\
\text { of Street } \\
\text { Characteristics for } \\
\text { Walking } \\
\text { Jenny } \\
\text { Ernawati }{ }^{\star}(2016)\end{array}$ & $\begin{array}{l}\text { local people's } \\
\text { preference of street } \\
\text { characteristics for } \\
\text { walking with } 300 \\
\text { respondents }\end{array}$ & $\begin{array}{l}\text { The five factors account for } \\
51.7 \% \text { of the variance in } \\
\text { local people's preference of } \\
\text { street characteristics for } \\
\text { walking. }\end{array}$ & $\begin{array}{l}\text { further study is } \\
\text { necessary to test the } \\
\text { consistency of the } \\
\text { scale in various } \\
\text { studies of the } \\
\text { street characteristic } \\
\text { for walking. }\end{array}$ \\
\hline
\end{tabular}




\begin{tabular}{|c|c|c|c|c|}
\hline & $\begin{array}{l}\text { Obesity } \\
\text { Physidy I. I / Asian } \\
\text { Activity, Spatial } \\
\text { Environmental } \\
\text { Characteristics } \\
\text { in } \\
\text { Three Types of } \\
\text { Residential } \\
\text { Settings } \\
\text { Ebru Cubukcua, } \\
\text { Burcin } \\
\text { Hepguzela, } \\
\text { Burak Tumerb, } \\
\text { Zeynep } \\
\text { Onderc(2014) }\end{array}$ & $\begin{array}{l}\text { Planned and } \\
\text { Journat } \\
\text { unplanned } \\
\text { developments } \\
\text { for low, } \\
\text { moderate, and } \\
\text { high income } \\
\text { neighborhoods. } \\
\text { Three spatial } \\
\text { setting } \\
\text { characteristics }\end{array}$ & $\begin{array}{l}\text { Results showed shes } \\
\text { ehand } \\
\text { differences in variables }\end{array}$ & $\begin{array}{l}\text { Aore } 299 \text { earch is on } \\
\text { call for obesity and } \\
\text { physical activity } \\
\text { investigation in } \\
\text { developing countries }\end{array}$ \\
\hline 30 & $\begin{array}{l}\text { Identification of } \\
\text { Child-Friendly } \\
\text { Environments } \\
\text { in Poor } \\
\text { Neighborhoods } \\
\text { Sharareh } \\
\text { Ghanbari- } \\
\text { Azarneir Sara } \\
\text { Anbari, Seyed- } \\
\text { Bagher } \\
\text { Hosseini, } \\
\text { Seyed-Abbas } \\
\text { Yazdanfar(201 } \\
\text { 5) }\end{array}$ & $\begin{array}{l}40 \text { Children 6- } \\
12 \text { years of age } \\
\text { from a poor } \\
\text { neighborhood }\end{array}$ & $\begin{array}{l}\text { Children preferred more } \\
\text { challenging places, } \\
\text { flexible spaces, locations } \\
\text { with the chance of } \\
\text { finding new friends. They } \\
\text { preferred natural } \\
\text { elements in their play } \\
\text { settings. }\end{array}$ & $\begin{array}{l}\text { Future studies could } \\
\text { concentrate on } \\
\text { these elements' } \\
\text { features. }\end{array}$ \\
\hline
\end{tabular}

\subsection{Results and Discussions}

This study appraised independent mobility of children in military barracks community in developing countries by looking at past works. It revealed significant connection between the independent mobility through walking as the most active travel and mode in improving the wellbeing and quality of life of children in military barrack community. An overview of military geography, culture and barracks built environment was examined, active travel mode parameters were considered including use of car, public transport, biking and walking based on lessons from developed countries. Most of the studies used mixed mode of quantitative and qualitative research methodology approach owing to the complex nature of researches on children and environment. Greater percentages $(90 \%)$ of journal articles reviewed were obtained from Science Direct through UTM e-library from 2007 to 2018 and AMAR Journal articles from 2012 to 2017. Outline in Table 1 showed records of articles reviewed by title, authors, and year of publications in the first column. The publications are between 2007-2018 with greater number (70\%) of studies conducted in developed countries of Europe and few developing countries of Asia. Most of the studies employed multi-disciplinary approach to examine contending issues which are cross- sectional in nature. Not less than $60 \%$ of the studies seek to investigate the association of independent mobility and child-friendly environment. The age categories of children were taken into consideration as well as gender. 
The location and climate were not properly considered in some studies. The research parameters were highlighted in the second column of Table 1. In order to confirm that independent mobility is significant in promoting a child-friendly environment, many of the studies laid emphasis on active travel mode in favour of walking or cycling to improve health through physical activity. Furthermore, effects of independent mobility on social and physical environment, need for policies on parents licence, measures to ensure safety within certain range, time and destination were stressed. Importance of natural outdoor spaces to social and cognitive development of children was emphasized. The strength of association between independent mobility and physical environment is high in all the studies reviewed.

\subsection{Conclusion}

The literature review covers active travel modes in home-school journey and other destinations. The significance of environment to children was stressed and the need to uphold commitment in creating a good living condition for children's human right was incorporated. Notable indicators and significant factors militating against natural children's place were highlighted to be explored in further studies and peculiarity of children's place in the military barracks. Similarly, longitudinal studies examining patterns and predictors of active travel and independent mobility to school and other destinations are scanty. The extent of the restriction needed to be studied and a model developed to employ the concept of independent mobility to enhance child-friendly military barracks. Furthermore, the need for policies on parents' license, measures to ensure safety within certain range, time and destination was found to be necessary. Importance of natural outdoor spaces to social and cognitive developments of children was emphasized to promote good health through physical activities. The findings in the reviewed studies identified parameters as a major determinant of outcome. Moreover, sensitivity and wrong perception concerning military environment have accounted for dearth of information and low level of research in the built environment. Considering the barracks as condominium housing that allows shared facilities, results from residential estates and campuses are applicable to military barracks. Consequently, there will be potential benefit in extending the policy of walking to improve independent mobility of children to school and open spaces. Therefore, emphasis on increasing the amount of incidental activities necessary to reduce sedentary lifestyle by developing barracks community with mixed land use and promoting active transport modes of walking or cyclingfriendly environment will improve quality of life for children.

\section{References}

Chaudhury, M., Oliver, M., Badland, H.M., Mavoa, S., 2015. Children's independent mobility and the importance of public open spaces. In: Horton, J., Evans, B. (Eds.), Geographies of Children and Young People. Springer, UK. Cubukcu, E., Hepguzel, B., Tumer, B., \& Onder, Z. (2015). Obesity , Physical Activity , Spatial Environmental Characteristics in Three. 
Types of Residential Settings. Procedia - Social and Behavioral Sciences, 202(December 2014), 382-388. https://doi.org/10.1016/j.sbspro.2015.08.242.

Ernawati, J. (2016). Dimensions Underlying Local People 's Preference of Stre et Characteristics for Walking. Procedia - Social and Behavioral Sciences, 234, 461-469. https://doi.org/10.1016/j.sbspro.2016.10.264.

Fyhri, A., \& Hjorthol, R. (2009). Children 's independent mobility to school, friends and leisure activities. Journal of Transport Geography, 17(5), 377-384. https://doi.org/10.1016/j.jtrangeo.2008.10.010.

Ghanbari-azarneir, S., Anbari, S., \& Hosseini, S. (2015). Identification of Child-Friendly Environments in Poor Neighborhoods. Procedia - Social and Behavioral Sciences, 201(February), 19-29. https://doi.org/10.1016/j.sbspro.2015.08.114.

Glenn, N. M. (2017). Social Science \& Medicine Young adults â€TM experiences of neighbourhood smoking-related norms and practices: A qualitative study exploring place-based social inequalities in smoking, 189, 17-24. https://doi.org/10.1016/j.socscimed.2017.07.021.

Hanapi, N. L., \& Ahmad, S. S. (2016). A Review on Environmental Characteristic that Influence Children Physical Activities in Low Cost Housing. Procedia - Social and Behavioral Sciences, 222, 19-27. https://doi.org/10.1016/j.sbspro.2016.05.166.

HTACOS (2018). Harmonised Terms and Condition of Service for Armed Forces of Nigeria. Revised pg224 Kolodinsky, J. M., Patrick, T., Propen, D., Putnam, M. E., Roche, E., \& Sawyer, W. R. (2013). It is not how far you go, it is whether you can get there : modeling the effects of mobility on quality of life in rural New England. Journal of Transport Geography, 31, 113-122. https://doi.org/10.1016/j.jtrangeo.2013.05.011.

Kyttä, M., Hirvonen, J., Rudner, J., Pirjola, I., \& Laatikainen, T. (2015). The last free-range children ? Children ' s independent mobility in Finland in the 1990s and 2010s, 47, 1-12. https://doi.org/10.1016/j.jtrangeo.2015.07.004.

Lin, E., Witten, K., Oliver, M., Carroll, P., Asiasiga, L., Badland, H., \& Parker, K. (2017). Health \& Place Social and built-environment factors related to children â€TM $s$ independent mobility: The importance of neighbourhood cohesion and connectedness. Health \& Place, 46(January), 107-113. https://doi.org/10.1016/j.healthplace.2017.05.002.

Mitra, R., \& Buliung, R. N. (2014). The influence of neighborhood environment and household travel interactions on school travel behavior: an exploration using geographically-weighted models. JOURNAL OF TRANSPORT OF GEOGRRAPHY, 36, 69-78. https://doi.org/10.1016/j.jtrangeo.2014.03.002.

Okafor, B.N (2016) in his publication in international journal of physical and human geography titled: fitted green buildings for Nigeria public institution towards effective administration of public properties.

Tranter, P., \& Sharpe, S. (2012). Disney-Pixar to the rescue : harnessing positive affect for enhancing children ' $s$ active mobility. Journal of Transport Geography, 20(1), 34-40. https://doi.org/10.1016/j.jtrangeo.2011.04.006.

Timperio et al. (2008). Playing it safe : The influence of neighbourhood safety on children 's physical activity - A review, 14, 217-227. https://doi.org/10.1016/j.healthplace.2007.06.004

Veitch, J., Carver, A., Salmon, J., Abbott, G., Ball, K., Crawford, D., ... Timperio, A. (2017). Health \& Place What predicts children â $€^{\mathrm{TM}} \mathrm{s}$ active transport and independent mobility in disadvantaged neighborhoods ? Health \& Place, 44(February), 103-109. https://doi.org/10.1016/j.healthplace.2017.02.003

Villanueva et al. (2012). Health \& Place How far do children travel from their homes ? Exploring children 's activity spaces in their neighborhood. Health \& Place, 18(2), 263-273. https://doi.org/10.1016/j.healthplace.2011.09.019. 
Daodu, T., \& Said, I. / Asian Journal of Environment-Behaviour Studies (ajE-Bs), 3(11) Nov / Dec 2018 (p1-18)

Zhang, R., Yao, E., \& Liu, Z. (2017). School travel mode choice in Beijing , China. Journal of Transport Geography, 62(August 2016), 98-110. https://doi.org/10.1016/j.jtrangeo.2017.06.001. 